\title{
Journeys to Teaching Qualitative Research Methods Online
}

\author{
Kathryn Roulston, Kathleen deMarrais, and Trena M. Paulus
}

\begin{abstract}
Teaching in online spaces requires new roles and competencies. Presented as autoethnographic narratives, three faculty members describe their journeys into online graduate instruction in qualitative research methods. Areas of growth included effective course design and planning and strategies for building community. Challenges included keeping up with the technology and finding adequate resources. These narratives provide potential issues for consideration by faculty new to online instruction.
\end{abstract}

\section{Background}

While the potential of online modes of delivery such as Massive Open Online Courses (MOOCs) to provide "education for all" and revolutionize higher education presaged by educational technology entrepreneurs such as Daphne Koller and Sebastian Thrun (cofounders of Coursera and Udacity, respectively) have yet to occur (Rohs \& Ganz, 2015), a different revolution is underway. Numerous online portals are attracting students for professional development purposes (Corcoran, 2016) as well as recreation and leisure pursuits (Warner, 2014). In higher education, the attraction of online instruction is reflected in the numbers of students taking online coursework. Fourteen percent (2.8 million) of university students took all coursework at a distance in the fall of 2014 (Allen, Seaman, Poulin, \& Straut, 2016, p. 10). At the same time, $67 \%$ of higher education students in the U.S. enrolled in "at least one" distance course do so at public institutions (p. 12). Yet, public institutions lag in enrollments when compared to private for-profit institutions, with only $27 \%$ of students taking at least one distance course, as compared to $60 \%$ at private for-profits. Even while increasing numbers of students are taking online courses, some faculty continue to be unconvinced of its merits. Allen et al. (2016) commented that: "A continuing failure of online education has been the inability to convince its most important audience - higher education faculty members - of its worth" (p. 26).

While an increasing number of faculty members are teaching online at public institutions, little is known about their experiences, since research has tended to focus on faculty working at online institutions (Yick, Patrick, \& Costin, 2005) or part-time for distance institutions (Dolan, 2011; Ng, 2006)—which, in the US, continue to be the main purveyors of online coursework. Researchers have reported on their transition to online teaching in mathematics education (Fernández, 2014), occupational therapy (Farber, 2013) and nursing (Myers, Mixer, Wyatt, Paulus, \& Lee, 2011). A small number of articles provide descriptive accounts of the online delivery of coursework on qualitative research methods. Bender and Hill (2016) described the strategies used to teach undergraduate coursework in qualitative research methods online; Kaczynski and Kelly (2004) discuss the integration of Qualitative Data Analysis (QDA) software (NVivo) in an online three-course sequence on qualitative research methods; Maggio, Chenail, 
and Todd (2001) provide accounts of their integration of technology-mediated learning strategies in teaching coursework on family of origin, qualitative research methods, and family therapy respectively; Moore and Janzen (2012) present a dialogue between and instructor and student concerning the online delivery of a coursework on qualitative inquiry in the field of health; and Ryen (2009) describes the planning and implementation of online delivery of qualitative research methods coursework in a master's program in Development Management. What all of these accounts have in common is that they provide descriptive accounts of the planning and implementation of teaching qualitative research online.

This paper focuses on the transitional journeys into online teaching described by instructors of qualitative inquiry. Five in-depth qualitative interviews were conducted by a graduate assistant. ${ }^{1}$ Two interviews were conducted with the first and second authors and one with the third author for a total duration of five and one-half hours. Narratives were reduced to key ideas (Kim, 2016) relevant to understanding individual transitions and arranged as autoethnographic tales (Chang, 2008; Marx, Housen, \& Tapu, 2016). We organize these tales by first introducing the context of our work, our first experiences with online teaching, our approaches to course design, how we manage the weekly teaching schedule, the importance of building community, and reflections both on what challenges us and what we enjoy.

\section{The Teaching Context}

Around 2010, the first and second authors began to explore alternative models of delivery to the weekly three-hour face-to-face meetings that were typically used. In part, this was to provide access to students who were not in Athens, Georgia. At the time, our college did not provide a great deal of support for online instruction. We began by experimenting with hybrid delivery prior to offering a fully online version of the Interdisciplinary Qualitative Studies certificate program in 2014. By then, the institution had begun to support faculty teaching online by establishing an Office of Online Learning. We also searched for and hired an additional faculty member with extensive expertise in online instruction (Trena). These are our stories...

\section{Where We Began}

It's 1986, and I'm at home in Bethel, Alaska, which is 400 miles due west of Anchorage, not far from the Bering Sea. I've called into a central audio conferencing site, and I'm about to talk to my students, who come from all over: Barrow, Fairbanks, Bethel, Nome, and Dillingham. I'm just about to learn what the weather is like where they are. This is my first experience with distance education, and it isn't the same as face-to-face. I really get to know the students and it's fun. I'm comfortable with it. (Kathleen)

It's the late 1990s, and I'm a doctoral student at the University of Queensland, Australia, listening to feminist scholar, Dale Spender. She is forecasting the future of higher education in the age of the Worldwide Web. Spender tells of a time when students will have access to instructors at other institutions anywhere in the world via online coursework. Students will choose their instructors! I think of the obstacles: the cost of technology, the technical skills required, and so on. I reject Spender's prescience altogether. (Kathy) 
It's 2000, and I'm a doctoral student in Bloomington, Indiana and have recently started teaching a Master's course for a completely online university. I have no real idea what I am doing yet, and I quickly learn that interacting with adult students who are working full time (most of whom are likely much older than me) only through asynchronous forums and e-mail is fraught with danger. Being from the Midwest, I focus only on the tasks at hand with no real thought to relationship building or getting to know the students personally, so when students constantly turn assignments in late and don't post to the discussion forums I am mystified. Frustration levels rise all around and I vow never to do this again.

It's now 2017, and each of us feels comfortable teaching our content area-qualitative research methods -in online environments that make use of a variety of asynchronous and synchronous tools. Our work as teachers is informed by the principles of qualitative pedagogy - a term coined by deMarrais in the late 1990 s and outlined by Preissle and deMarrais $(2011,2015)$ as an approach that

assumes that the principles guiding the practices of qualitative research should guide instruction in qualitative research, and it represents an overall approach to teaching qualitative research to novices and others new to qualitative traditions. Our position is that we ought to teach our research practices in ways faithful to how we practice research and scholarship. The qualitative pedagogy we advocate is responsive, reflexive, recursive, reflective, and contextual. (Preissle \& deMarrais, 2011, p. 32) (Italics in original)

It is in the spirit of this qualitative pedagogy we have approached sharing our learning about our own teaching in this paper. Here are our stories...

Kathy. When our program first talked about offering online coursework, we met with a representative from the Center for Teaching and Learning who recommended blended delivery ${ }^{2}$ (Garrison \& Vaughan, 2008) as a way to transition from face-to-face to completely online teaching. Beginning in 2011, I sought student feedback as to what worked in online contexts through a series of teacher research studies (Hubbard \& Power, 2003) in which I examined what went on in my courses. I also took online classes in different formats. By 2014 I had taught several hybrid classes, engaged in research of my practice, taken a variety of online classes, participated in professional development opportunities at my university, and completed the Certificate in Online Teaching offered by the Online Consortium (formerly Sloan Consortium). While I do not have a degree in instructional technology per se, I had been involved in several technology projects as a K-12 teacher and had worked in an ACOT school. ${ }^{3}$ Although I like to try new things, it was still challenging to upgrade my skills and learn to use different tools.

Kathleen. I'm an early adopter and like figuring things out. I started using hybrid delivery formats before I tried teaching fully online. When I was first introduced to computers in the 1980s, I used to react to technology_ "I hate it! I'm not ever doing it." Now I don't. I'm much more patient with myself. I've taken workshops, and spent time learning new tools like ScreenFlow. If I can't work it out myself, I am able to get help just in the nick of time. "OK, here's a problem. Can somebody help me with this?" Fortunately, there are usually resources available. Each time I teach a course, my goal is to learn one new thing. We really worked together a lot on the development of the courses. What we are trying to do is to have 
the same look and feel across the certificate program. And we have had really good support from the Office of Online Learning.

Trena. The first online class I taught was a master's course in instructional design in 1999 for an online university. It used asynchronous discussion and email. Then I helped put the master's program in instructional design online in the department where I was doing my doctoral degree. It was still asynchronous and text-based with a few short videos or podcasts. For my dissertation research, I studied how small groups work together online to complete tasks. When I became an assistant professor, I didn't teach online for a long time because the revolution hadn't hit that university yet. When it did, the goal of the program was to increase enrollment so we did away with our on-campus program and went completely online. We intentionally used a synchronous and asynchronous model because my colleague and I really felt like that model was the best of both worlds, based on our own experiences and research in the field.

Institutional resources for supporting faculty in online teaching vary quite a bit from place to place, which can be a challenge. I'm glad that there was phenomenal support for faculty at my previous institution when it comes to teaching and technology. I got a lot out of that. I try to get just-in-time help, like when I was ready to do a Camtasia video I asked someone to come over and show me. I'm comfortable with the technology. It doesn't intimidate me or make me nervous. I think it's easier for me to take it up maybe than for other faculty.

Not everyone who is interested in teaching online is an early adopter or a tech-wizard, so there is need for support and professional development when transitioning to online teaching. Faculty members have different learning preferences also. Some benefit from learning experientially by being online learners; others will make use of just-in-time support and instruction in how to use new technologies; and those whose research encompasses the Scholarship of Teaching and Learning (SoTL) will enhance their teaching practice through conducting research on their own teaching. However professional development is undertaken, teachers transitioning to online contexts do need to develop expertise in planning and designing online instruction and making effective use of new technologies. These professional development opportunities will be more robust when supported by findings from current research that discuss the expanded roles of online instructors that involve responsibilities for curriculum development, course design, and course administration and facilitation. Thus, there is need for professional development opportunities to be tailored to be responsive, reflexive, recursive, reflective, and contextual with respect to the needs and learning preferences of faculty. 


\section{Course Design, Preparation, and Planning}

Kathleen. We decide together as a program on the learning outcomes and gear assignments and the discussion posts to those. I look at the assignments, and I figure out how I am going to structure each weekly post to meet the outcomes of the course. What we found worked is that students apply what they have learned from the readings in their weekly writing activities. We work towards application: create this, or develop that, with the assignments building towards the final paper. I have a system where I model what I am teaching; we read about it, we do guided practice, then independent practice. Evaluation follows in an action research cycle. We teach qualitative research the way we do qualitative research (Preissle \& deMarrais, 2011, 2015).

Trena. I want to support my colleagues, but it's also been tough because program design decisions were made before I arrived. I believe in synchronous interaction but that was not the norm. I've had to reconcile what I have experienced with the institutional realities. I have personal beliefs about what works, but also have to work with people who've had different experiences that are also valid. So, we try to make the best decisions for the program.

I design the courses week by week. I map out the course schedule first and start early to find out what nights people are free for the synchronous sessions. I often have guest speakers so I invite them early on to get those dates on the calendar. Once the syllabus and the schedule are complete, I set up the platform with the different modules. I typically open the whole course so students can see it all at once, although usually I'm developing it one step ahead of them the first time it's offered. I do introductory videos that are more relational than content delivery. They reflect back on what happened the previous week, remind students of things that have come up and answer questions. As the course moves along, I tailor discussion questions to address issues that have come up.

Kathy. There's a lot of preparation. Kathleen and I settled on a weekly module to structure each course. Each module contains three folders - an introductory folder with a checklist, a content folder with an audio presentation or screencast and links to other materials, and an activities folder. For good learning to occur online, the technology should not be a hindrance. However, you organize the course needs to be easy and available on multiple platforms. Students don't want to click too many times because they'll get lost, very quickly. Yet the technologies continually change. When the learning management system (LMS) was updated, my audio presentations ${ }^{4}$ no longer worked, so I had to buy new software and convert all of the presentations. So I spend a lot of time on course development and updating materials.

Kathleen. I want materials that I can refer students to in multiple classes, so I set up all modules ahead of time. The first time I did a fully online course, I tried to make sure that each module was up a week ahead of time. It was really hard to do that... But now I feel really comfortable with the course. I spend a lot of time on the first module so the course gets off to a good start. I make sure that I do not add dates or refer to specific students in course content because I want to use material again. I made that mistake early on-I was trying to really relate to the students by incorporating them into presentations. But you can't use them again. So, I've gotten smarter. 
Teaching online, like learning online, involves time (Spector, 2005)_but creating and sharing plans, approaches, and resources across the program as a team helps. There are many best practices that can help ensure that a course "works," and we've tried to collaboratively create practices specific to our program. Although course preparation and planning entails extensive time, once a course is developed, aside from continuous revisions, the structure and content is reusable, thus enabling a robust course in future semesters with less preparation.

\section{Managing the Weekly Schedule}

Kathleen. I prepare a schedule that details what we will do each week, with the learning outcomes, the readings, the materials, and then the activities. I walk students through this and have them rely on the schedule. I have a forum in which I can answer general questions and one for technology issues where they can help each other in case I'm not online. I make sure that there is an introduction to each module, a list of learning objectives, and a checklist of what they have to do. For example, "Read the assignment steps, here's the chapter, view the case study PowerPoint, complete Writing Exercise 1.1, review the video." We have found that it's useful to have a structure that the students become familiar with. They know what's coming and the course runs smoothly.

Kathy. I structure each week in the same way because it is helpful for people who are working full-time and have families, to know that they need to post on the same day each week. That's helpful for the majority, although a few would rather have variation. I generally don't answer emails on the weekends — if it's urgent, I'Il just send students a note. I read all students' posts and write a group response or make a screencast. The more I post in the threads, the less students are going to respond to one another, so I try to keep that to a minimum. If I see misunderstandings going on, I will intervene and try to help. I use rubrics to grade, and I make those explicit to the students. What I try to do is go into the grading system and write my comments on students' responses after their initial post. Then once students have finished their discussion for the week I'll post grades with comments for everyone. So, you know, "Great job" or "You need to do this" or whatever. Some people do need a prod. I will email and say, "You know, I haven't heard from you this week, what's going on?"

Trena. At the beginning of each week I post an opening video. That's when the class should start looking at materials. Then, students make their initial posts to the discussions as written or video responses. I read through all the discussion posts and if there are questions that I'm probably the only one that can answer or something really interesting, I will post a response, and use that information to plan the week's synchronous session. If they attend the synchronous session, students don't have to participate in discussions for the rest of the week. If they don't, they need to watch and post a reflection on the recorded synchronous session. I don't do long synthesis posts, though they're probably really helpful to remember the highlights. Instead I summarize the previous week as part of my opening video for the next week, in that way providing continuity across the modules. 
In the weeks that assignments are due, students are not doing new readings and discussions because that is not manageable. I try to get assignments returned within a week. I think that's really important online. I give individual feedback on participation about one third of the way through the course. I don't require students to make a minimum number of posts because if you do that, they will post exactly that many. So I tell them how many posts they've made relative to other students in the class and what kind of grade that will earn them. The LMS records how much time students spend reading and how many posts they've read, so I remind them that I can see that too.

While the structure throughout the semester is predictable, we strive to design challenging qualitative assignments and provide discussion prompts to keep students' interest levels high and to support their research skills as they move toward dissertations. While we each have a different approach to how we facilitate each course and manage the weekly schedule, we share goals. These include systematically designing courses that are clearly organized and easy to navigate, providing timely feedback, and encouraging interaction among students with the intent that learners engage in a meaningful array of authentic activities that develop knowledge and expertise in the conduct of qualitative research.

\section{Building Community With Students Online}

Kathy. While building community is invaluable, I'm not entirely sure what you have to do to foster that. Students have to be willing to engage with one another in authentic ways. I think you have to build in peer review and ways for students to ask genuine questions of one another. Whether a course sparks into a community that outlives the course is uncertain, but I know that it has happened.

People take an online course because they want to do it anywhere, anytime. I use synchronous meetings to let students know what's coming up, provide opportunities to ask questions, and talk about topics that have come up in the discussions. I typically give a short presentation, and I try to allocate time for students to talk to one another in small groups. Meetings are recorded for those who can't attend.

As an instructor, you have to share, too. I try to be supportive of students - to recognize they are working hard. I'll send jokes, little pictures and use apps like Tellegami or Voki, not so much for the content, but for fun. It's not all about the content. We need to recognize that we're all people who are working hard and we can help one another.

Trena. Teaching online requires something different than lecturing. I don't see discussions as a place for students to display their knowledge as much as a chance to interact and read what other people's ideas are. I ask students to be sure everybody has a response. If they are not attending the synchronous session, they need to contribute to the asynchronous forums. Online courses used to have attrition rates of $50 \%$ or more because there was no interaction or engagement. The chat function in the synchronous meetings adds one more layer of interaction. While I am doing my mini-lecture or while the guest speaker is talking, students can ask questions via chat. It's great for that, I really like it a lot. 
The hardest thing about teaching online is that it is really easy to jump to conclusions and assume the worst. Students can be dehumanized really quickly when you're only interacting with them through email. This is why I like students to see me on video; this is why I like having synchronous sessions. It humanizes us and builds community. Reaching the students who are not as active as you think they should be, but who might be doing as much as they are able to, is a challenge. Not everybody wants to be overachievers in online classes, so figuring out the right amount of reaching out can be tricky.

Kathleen. If you never see the students in person, the challenge is to build that relationship. I have to get my personality on that screen and get to know theirs. I have found that the students really want to see your face. I try to make screencasts more personal. If my cat comes and sits with me, I'll say something about the cat, or I'Il do it at home where they can see my workspace. I have a video at my house with my chickens!

I'Il politely point students back to the resources when asked questions, because you have to continually build this relationship. I say, "Oh, you probably overlooked that. Now, look here, look there, or look here." For synchronous interaction, I have optional "coffee hours" where students come in and we talk about their questions. I keep it to an hour and record it if they can't come.

If students take an online course because they didn't feel like driving down two blocks to get to the face-to-face class and thought it was going to be easier, it doesn't work. The instructor has to figure out why the students took the class in the first place and then try to reach them wherever they are. I started out with "personalized instruction" in 1971. I think that the online instruction is really very much like that. You have to put the structure in place and the design; then you have to personalize it for each student. We treat people as individuals and take them from where they are.

Previously high attrition rates for online programs have been reduced since educators and researchers realized the importance of building a community to keep students engaged. We use a variety of strategies for this, including using a range of asynchronous and synchronous tools that facilitate interaction among students and the instructor. The Community of Inquiry model (Garrison, Anderson, \& Archer, 2000, 2001; Garrison \& Vaughan, 2008) that advocates for a balance between teaching, cognitive and social presence has been helpful in understanding what is needed to promote the development of a healthy online community in our classes. Still, students are motivated to take online courses for a variety of reasons, including convenience. Deciding on the best means to develop an effective online community is something of a challenge for instructors, given the range of options available. This can be accomplished through the use of synchronous meetings where the instructor and students are visible to one another via video, or through regular interaction in the forums. Creating personal connections and working relationships among students helps. This can be facilitated through peer-review activities and through thoughtful and well-designed group activities. 


\section{Challenges of Teaching Online}

Kathleen. It's hard to create time for course development a semester ahead. As Department Head, I was able to embed one of the designers from the Office of Online Learning in our department for 20 hours a week ... that was the best help. Trying to balance research, administration, and teaching is really hard. Sometimes there's been a $\$ 5,000$ stipend for the summer to develop a course.... you can do some with that, but it's not going to cover much time.

Kathy. I can't produce the absolutely gorgeous things you might see in some courses. I've felt frustrated over the years because to do fantastic online education you probably need a production team. If a YouTube video isn't interesting in the first three seconds, you are probably going to go to something else and I fear that will happen in my course. The challenge for me is to give something value added to understanding this content which might not be that visually appealing.

Trena. I don't find the $\mathrm{LMS}^{5}$ at the university exciting and I find myself wanting to "like" people's posts all the time. In Discourse ${ }^{6}$ that feature allowed you to signal "I've read this" without having to write out a reply. You can't do that in our LMS, but I know that's just social media culture influencing how we think about interacting. Tagging would be nice, too, if there was a post in the LMS I'd like to be able to say, "Maybe John can help," but there's no way to tag John and that's really handy with the Discourse site. You can bring somebody into the conversation by tagging them like you can on Facebook. I just feel like the LMS will catch up eventually.

Advocating for online courses to be recognized as having integrity and high quality is really important to me. There is still a stigma attached to it. People enroll thinking it means independent study and I've had students say, "Oh I'm just going to catch up later." I'm like, "You can't catch up, this isn't independent study. If you weren't here posting all week, you weren't here." We're fighting an uphill battle where students, administrators, and faculty all still believe that the only reason to take an online class is because it's convenient. This is why I think the synchronous component is important. Students have to be willing to dedicate at least a few hours of the week to the class. It can be place independent, but I don't think it can be both time and place independent for 15 weeks and be as successful as when you are making that commitment to sacrifice a certain period of time to be present with other people in real time.

There are many reasons for teaching and learning online and many models of online delivery and learning. Yet, online learning still suffers from stigmas in the larger community. We are continually challenged to design and deliver courses that meet our goals, are within our technological grasp, and convey the integrity of our courses to others.

Kathleen. I feel bad if I don't get students' papers back to them really quickly. I feel guilty: "Oh my God! I haven't been on, I have to go check. I hope everybody's OK." I don't want to have them left out there alone. So, trying to keep up with it and trying to respond in a timely manner when everything else has to be dealt with is tough. If something has come up to delay my responses, I try to communicate that to students and encourage them to do the same. Good communication with students and between students is key for keeping the course running smoothly. 
Kathy. As an instructor, I don't have the skills to fix some of the technical problems that I've encountered in using synchronous tools and used to get really angry. But some of these are out of the control of the instructor and a software engineer is needed to fix them. I'm aware that students, particularly if they're new to the online class, have high levels of anxiety. The technology is always going to change. Things aren't going to work the way you expect them to, so if you can't handle that kind of thing, you probably shouldn't be doing this. Now I let students know the plan: if this happens, this is what you need to do. We have to work through this together.

Trena. There is a huge reliance on the technology that makes this all possible. Knowing that when the grid goes down, it's all over, is a scary feeling. That's why the technology glitches that we face make us so frustrated: because we rely so much on good Internet connection, computers that work, electricity...When my Internet connection went down while teaching from home it made me realize how precarious everything is. Just like with backpacking, if a bear comes and eats you, there's nothing you can do. Or one misstep and you have a sprained ankle out in the wilderness-you're done for! So it's all great until one thing happens and you're like "Oh!" When our Internet went down I thought to myself that if this happens again, I can't do this because I can't have things not working while students are in class.

The immediacy of technological problems and responding to online students' needs and anxieties challenges instructors in ways that quickly engage the emotions, particularly negative emotions (Bennett, 2014). Without a high level of support and technological expertise, this work is difficult. While our online courses appear well put together after years of development, the faculty emotions of getting to that point, as well as the time required, are not so evident to those who have not engaged in this work.

\section{What We Like About Teaching Online}

Trena. I'm glad I teach online. I really like being able to bring in speakers from other places. In one class, there were people gathering from all over the world. I like that you get diverse perspectives. The whole reason distance education began was to give people opportunities that they wouldn't otherwise have. I get energized and excited after my synchronous sessions. Maybe it's just the miracle of it, that I can be sitting in my home office, interacting with all of my students in a way that I feel is really meaningful and that I think they've enjoyed-having a chance to talk about what we've been discussing in the forums. I find it really rewarding when we've had a successful synchronous session. I also like the visibility of it, the neatness and orderliness-it's like backpacking (my new favorite metaphor for online teaching). The whole class is right there and you can access it at any time, and yet there's also dynamic, interactive discussions going on. And you're not tied to a particular place, just like with backpacking, you put everything in your backpack and you go someplace else and you set it all up again.

Kathy. You get to know your students in a different way than you would otherwise. Because everything's in writing, I learn otherwise unknowable things about students that they share. As far as the academic outcomes, I can learn much faster who is doing what and what kind of misunderstandings they might 
have or who has expertise in areas that I might never imagine. There's equity in talk time; everyone's voice becomes public whereas in a face-to-face course, people who are very introverted or might be speaking English as a second language may choose to remain silent in a course and you never really get to know them. They can't do that in an online course.

Online coursework is more accessible and more convenient for commuter students. It's friendlier to adults who have families, who work full-time. I think that's a good thing. In graduate education, universities have really catered to full-time students who are privileged to get assistantships. Online courses seem much more like a collaboration. We have wonderful students who know so many things that we don't. And students share their knowledge. So I hope that somehow in the course, students will recognize the power of the personal learning network. ${ }^{7}$ In the future, people will be able to package their learning in many ways: face-to-face, independent online learning, and online interactions with others. I've come to a much greater appreciation of how we can help one another learn in online environments.

Kathleen. I really feel very pleased when things go well, when I can see student learning and questions. There's something about online teaching that I find very intriguing. Maybe it's the challenge of it$\mathrm{I}$ 'm going to do this really cool course and try these new technologies. When you teach face-to-face, there are always the students who want to be quiet in class. So, it's a challenge to attend to them and also to the extroverts who have to talk through what they're thinking about. And it doesn't leave space for the students who are sitting quietly. In an online class I get to know everybody. Even introverts have to put their work out there in writing. What they put out there is a reflection of what they are thinking and one would hope it would be their best work. And, if it's not, I can do something to correct that, and to provide better expectations for them or to say, "Hey, this isn't good enough. Sorry. Try a little harder next time!" So, I love my online students and teaching online even though it's much harder. It gives me more freedom in my work schedule. So, I don't have to be here Monday nights for three hours. I can work from home. If I weren't an administrator, I could spend my work hours more productively without wasting time commuting.

\section{Conclusion}

Even with the challenges of learning the technologies and spending the time needed for course development and instruction, we support online teaching and learning. As faculty members who value our freedom to work where we want when we want, pushing ourselves to learn to teach high-quality courses has been rewarding. We recognize that online teaching and learning is not for everyone-faculty or students. We appreciate the immense variety in how online educational programs might be delivered. With new technologies constantly being created, the possible ways to deliver quality online education will continue to grow.

We are not advocating a particular "best" approach to online instruction, but share our stories to illustrate the ways in which we as teachers have approached our own learning of new technologies and ways of working within hybrid and fully online environments. Through our individual and collective stories here, 
we illustrate our individual processes over time and ways we have come together as a faculty to support each other's learning and development as instructors. Our stories offer possibilities for approaching online teaching through qualitative pedagogy. As a concrete example of this approach to instruction, we might think of our pedagogy as a research design where we first examine the context of the study as well as our research purposes and goals. Our students are our participants as we take into consideration the context in which they come to the course and build and reflect on our relationships with them throughout the course. As researchers/teachers, we are sensitive to what is going on in the environment through continual reflection and reflexivity in order to make changes along the way and to work with the individual needs of the students as well as those of the instructor. Our pedagogy, like our research, leads to further growth, and more stories.

This growth might be thought of as a vast river of ideas.

Or maybe it's a tsunami.

Or a backpacking journey.

What should a teacher in the early part of the 21st Century do with the constant flow of new information, tools, and technologies?

We offer these stories to others who want to explore ${ }^{8}$

\section{Notes}

1. We thank our graduate assistants for their contributions, including Elizabeth Pope for conducting the interviews, and Erika Cooper for transcribing them.

2. There are many models for "blended" delivery and terminology used is not consistent across institutions. At our institution, "blended" delivery is used to refer to programs offered in ways that incorporate face-to-face and online delivery, and "hybrid" delivery is used to refer to coursework that incorporates face-to-face and online delivery.

3. Apple Classroom of Tomorrow.

4. Developed in Articulate Presenter.

5. The Learning Management System used at the institution is supported by Brightspace (formerly Desire2Learn).

6. Discourse is an online course management application available at discourse.org.

7. Rheingold (2012) provides ideas for how people can thrive online using social media to build a "personal learning network" that is generative and supportive.

8. This closing poem is generated from interview data and conversations among us. 


\section{References}

Allen, I. E., Seaman, J., Poulin, R., \& Straut, T. T. (2016). Online report card: Tracking online education in the United States. Retrieved from http://onlinelearningsurvey.com/reports/onlinereportcard.pdf

Bender, S., \& Hill, K. (2016). Pedagogical considerations for effectively teaching qualitative research to students in an online environment. The Journal of Effective Teaching, 16(2), 93-103.

Bennett, L. (2014). Putting in more: Emotional work in adopting online tools in teaching and learning practices. Teaching in Higher Education, 19(8), 919-930. doi:10.1080/13562517.2014.934343

Chang, H. (2008). Autoethnography as method. Walnut Creek, CA: Left Coast Press.

Corcoran, B. (April 25, 2016). What Sebastian Thrun has learned at Udacity. EdSurge. Retrieved from https://www.edsurge.com/news/2016-04-25-what-sebastian-thrun-has-learned-at-udacity

Dolan, V. L. B. (2011). The isolation of online adjunct faculty and its impact on their performance. International Review of Research in Open and Distributed Learning, 12(2), 16. Retrieved from http://dx.doi.org/10.19173/irrodl.v12i2.793

Farber, R. S. (2013). Distance education and teaching online: My journey from mystery to mastery. Occupational Therapy in Health Care, 27(3), 272-279. doi:10.3109/07380577.2013.809180

Fernández, E. (2014). Transitions from live to online teaching. PRIMUS, 24(1), 1-11. doi:10.1080/10511970.2013.821193

Garrison, D. R., Anderson, T., \& Archer, W. (2000). Critical inquiry in a text-based environment: Computer conferencing in higher education. The Internet and Higher Education, 2(2-3), 87-105.

Garrison, D. R., Anderson, T., \& Archer, W. (2001). Critical thinking, cognitive presence, and computer conferencing in distance education. American Journal of Distance Education, 15(1), 7-23. doi:10.1080/08923640109527071

Garrison, D. R., \& Vaughan, N. D. (2008). Blended learning in higher education: Framework, principles, and guidelines. San Francisco, CA: Jossey-Bass.

Hubbard, R. S., \& Power, B. M. (2003). The art of classroom inquiry: A handbook for teacher-researchers. Portsmouth, NH: Heinemann.

Kaczynski, D., \& Kelly, M. (November 2004). Curriculum development for teaching qualitative data analysis online. Paper presented at the QualIT2004: International Conference on Qualitative Research in IT \& IT in Qualitative Research, Brisbane, Australia. Retrieved from http://files.eric.ed.gov/fulltext/ED492010.pdf

Kim, J.-H. (2016). Understanding narrative inquiry. Los Angeles, CA: Sage.

Maggio, L. M., Chenail, R. J., \& Todd, T. (2001). Teaching family therapy in an electronic age. Journal of Systemic Therapies, 20(1), 12-23.

Marx, S., Housen, M., \& Tapu, C. (2016). Our international education: Stories of living, teaching and parenting abroad. Rotterdam: Sense.

Moore, S. L., \& Janzen, K. J. (2012). Walk with me: A qualitative research journey. Academic Exchange Quarterly, 16(3), 1096-1102. 
Myers, C. R., Mixer, S. J., Wyatt, T. H., Paulus, T., \& Lee, D. S. (2011). Making the move to blended learning: Reflections on a faculty development program. International Journal of Nursing Education Leadership, 8(1). doi:10.2202/1548-923X.2243

$\mathrm{Ng}$, C. F. (2006). Academics telecommuting in open and distance education universities: Issues, challenges and opportunities. International Review of Research in Open and Distributed Learning, 7(2). Retrieved from http://www.irrodl.org/index.php/irrodl/article/viewArticle/235/320

Preissle, J., \& deMarrais, K. (2011). Teaching qualitative research responsively. In N. Denzin \& M. D. Giardina (Eds.), Qualitative inquiry and global crisis (pp. 31-39). Walnut Creek, CA: Left Coast Press.

Preissle, J., \& deMarrais, K. (2015). Teaching reflexivity in qualitative research: Fostering a life style. In N. Denzin \& M. D. Giardina (Eds.), Qualitative inquiry and the politics of research (pp. 189-196). Walnut Creek, CA: Left Coast Press

Rheingold, H. (2012). Net smart: How to thrive online. Cambridge, MA: MIT Press.

Rohs, M., \& Ganz, M. (2015). MOOCs and the claim of education for all: A disillusion by empirical data. The International Review of Research in Open and Distributed Learning, 16(6). doi:10.19173/irrodl.v16i6.2033

Ryen, A. (2009). "Hi, Madam, I have a small question." Teaching QM online: Guide to a successful cross-cultural master-course. Qualitative Sociology Review, 5(3). Retrieved from http://www.qualitativesociologyreview.org/ENG/Volume14/QSR_5_3_Ryen.pdf

Spector, J. M. (2005). Time demands in online instruction. Distance Education, 26(1), 5-27. doi:10.1080/01587910500081251

Warner, J. (2014). Craftsy has created an arty online empire, one frosting curlicue and cross-stitch at a time. Retrieved from http://www.westword.com/news/craftsy-has-created-an-arty-online-empire-onefrosting-curlicue-and-cross-stitch-at-a-time-6283306

Yick, A. G., Patrick, P., \& Costin, A. (2005). Navigating distance and traditional higher education: Online faculty experiences. International Review of Research in Open \& Distance Learning, 6(2), $1 \mathrm{~V} 16$. Retrieved from http://www.irrodl.org/index.php/irrodl/article/view/235/320 


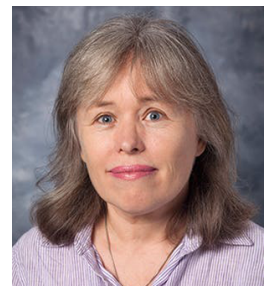

Kathryn Roulston is Professor in the Qualitative Research Program at the University of Georgia in Athens, Georgia, where she teaches qualitative research methods. Her research interests include qualitative research methods, qualitative interviewing, and analyses of talk-in-interaction. She is author of Reflective Interviewing: A Guide to Theory and Practice (2010), and has contributed chapters to The SAGE Handbook of Interview Research: The Complexity of the Craft (2012, 2nd ed.), The SAGE Handbook of Qualitative Data Analysis, The SAGE Handbook of Data Collection as well as articles to Qualitative Research, Qualitative Inquiry, and International Journal of Research and Method in Education.

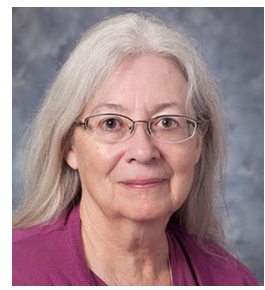

Kathleen deMarrais is a Professor in the Qualitative Research Program in the Department of Lifelong Education, Administration and Policy at the University of Georgia. Her research interests include qualitative research methods, qualitative pedagogy, and the role of philanthropic funding in educational policy and practice. Her most recent book (coeditor with J. Brewer) is Teach for America Counter Narratives: Alumni Speak Up and Speak Out (2015). Other books include Foundations for Research: Methods of Inquiry in Education and the Social Sciences (with Lapan, 2004), Inside Stories: Reflections on Qualitative Research, and The Way Schools Work: A Sociological Analysis (with LeCompte, 1999).

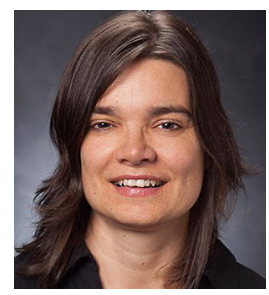

Trena M. Paulus is Professor of Qualitative Research Methods at the University of Georgia. She holds degrees in applied linguistics and instructional design and is author of Digital Tools for Qualitative Research (Sage, 2014). She studies the impact of new technologies on qualitative methods, specializing in the adaptation of language-based methodologies such as conversation, narrative, and discourse analysis to understand online talk. She is a founding member of the International Congress of Qualitative Inquiry's special interest group on Digital Tools for Qualitative Research. Her methodological text, Researching Online Talk: Looking for Insights, Transformation and Learning, will appear in 2018 (Routledge.) 
Kathryn Roulston, Kathleen deMarrais, and Trena M. Paulus

232 | LEARNing Landscapes | Autumn 2017, Vol. 11 No. 1 